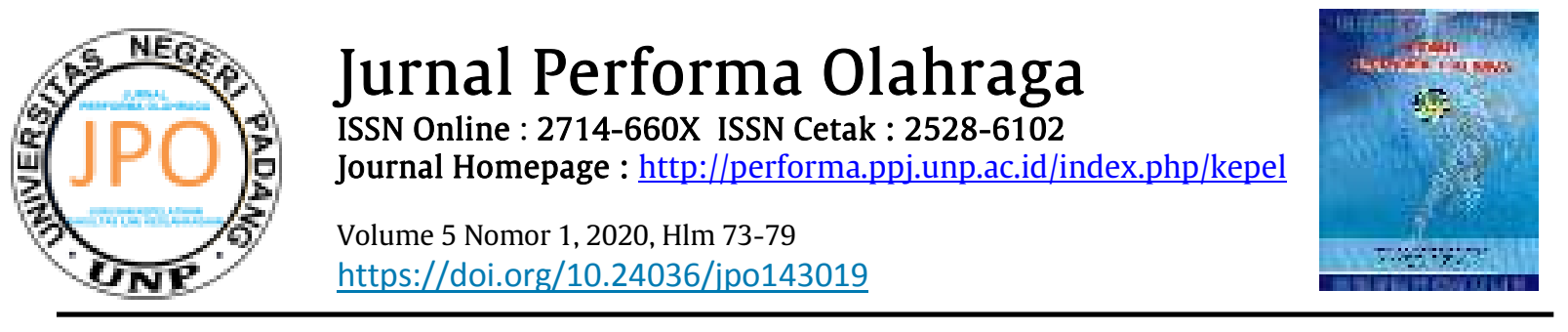

\title{
Pengaruh Latihan Jump To Box Terhadap Kemampuan Heading
}

\author{
Ikhwanul Arifan ${ }^{1}$, Eri Barlian ${ }^{1}$, Afrizal $^{1}$ \\ ${ }^{1}$ Fakultas Ilmu Keolahragaan, Universitas Negeri Padang, Indonesia \\ Universitas Negeri Padang, Indonesia.
}

\begin{tabular}{l} 
Informasi Artikel \\
\hline Diterima 15-06-2020 \\
Direvisi 20-06-2020 \\
Dipublikasikan 29-06-2020 \\
\hline
\end{tabular}

\section{Keyword:}

Jump To Box and Heading Ability

\begin{abstract}
This type of research is artificial experiments, this research aims to know the extent of the influence of exercise Jump To Box against the ability of the Heading, (Experimental Study on Soccer Club athlete The son of Pasaman). The population in this research is the son of The Club's soccer athletes Pasaman amounted to 43 people. This research sample taken from junior athletes as much as

20 people, the technique of taking sample by way of Porposive Sampling. The sample in this research is the junior athletes Football athletes is incorporated in the Football Club The son of Pasaman. The hypothesis presented in this study is an exercise Jump To Box give influence on the ability of the Headings on the Football Club's athletes The son of Pasaman.Data analysis uses the t-test, the results of the processing of data is 1) based on table t distribution with degrees of freedom (dk) $n-1$ (20-1 =

19) significant levels of 0.05 , then retrieved the table $t=2,093$. So $t$ count it $=t$ table $>6,734>2,093$ then Ho in decline while the Ha is received. In conclusion, there is a significant influence of exercise Jump To Box against the ability of the Heading.
\end{abstract}

(c) 2020 The Authors. Published by Universitas Negeri Padang. This is an open access article under the CC BY-NC-SA license https://creativecommons.org/licenses/by-nc-sa/4.0

\section{Penulis Korespondensi:}

Ikhwanul Arifan

Universitas Negeri Padang

Email: ikhwanularifan@fik.unp.ac.id

\section{PENDAHULUAN}

Olahraga merupakan salah satu bidang yang telah berkembang pesat diseluruh lapisanmasyarakat Indonesia danjuga di Negara-negara lainnya didunia, tanpa membedakan agama,usia, negara maupun aliran politik. Seorang individu yang melakukan olahraga secara terus menerus akan menjaga dan bahkan dapat meningkatkan kinerja tubuh, sehingga orang tersebut tidak mengelami performa yang menurun yang tentunya tidak diharapkan oleh atlet maupun pelatih(Haryanto \& Welis, 2019). Olahraga bukan lagi cuma sekedar berfungsi untuk menujuhidup sehat jasmani, tapi sakarang olahraga sudah menjadi salah satu profesi yangmenjanjikan dan dapat menjadi mata pencarianbagi seorang olahragawan yang berprestasi.Kemajuan ilmu dan teknologi menimbulkan perubahan yang cepat dalam berbagai tatanan kehidupan manusia, sehingga terjadinya globalisasi dan pasar bebas, Ridwan, M., \& Irawan, R. (2018). Oleh karena itu, untuk mencapai dan meningkatkan prestasi dalam olahraga perlu pembinaan dan pengembangan olahragawan secara terencana, berjenjang, dan berkelanjutan oleh pelatih, pemerintah, masyarakat dan organisasi lainnya. Salah satu olahraga yang perlu dibina dan ditingkatkan prestasinya adalah olahraga Sepakbola,karena olahraga Sepakbolabanyak di gemarimasyarakat,hal tersebut dapat dilihat daribanyaknyaklubSepakbola yang muncul di kalangan masyarakat. Hampir disetiap kecamatan, kabupaten maupun kota ada lapangan Sepakbola dan pertandinganpertandingan Sepakbolapun sering diadakan, seperti 
pertandingan antar klub, kota dan kabupaten. Masing-masing tim pasti menginginkan prestasi terbaik untuk atletatletnya.Untuk mencapai prestasi yang baik dalam olahraga Sepakboladibutuhkan pembinaan,sarana dan prasarana, ketekunan, kemauan yang kuat, penguasaanteknikdantaktik, mental yang kuat,dan pengalamanlatihanmaupunpertandingan yang cukup lama sertamempunyaikondisifisikatau stamina yang baik, Seperti yang dikemukakan oleh Syafruddin (2011:16) bahwa: Kegiatan olahraga banyak faktor pendukung yang mempengaruhi untuk mendapatkan prestasi, seperti : kondisi fisik, teknik, taktik, dan mental, Soniawan, V., \& Irawan, R. (2018). Dalam olahraga sepakbola disamping memiliki teknik, taktik, dan mental yang baik juga diperlukan penguasaan kondisi fisik yang baik pada atletnya.Menurut Arwandi, J., \& Ardianda, E. (2018) dalam upaya peningkatan prestasi para pemain sepakbola. Latihan adalah salah satu faktor yang sangat menentukan dalam pencapaian prestasi. Bentuk latihan yang dipilih juga akan sangat menentukan dalam mencapai target latihan yang diinginkan. Prestasi terbaik atau biasa disebut prestasi puncakdalam pembinaan olahraga diperlukan suatu proses persiapan yang terencana secara bertahap, terarah, sistimatis, dan berkelanjutan dengan kata lain bahwa proses persiapan dimaksud mencakup seluruh proses yang dimulai dari penyusunan program latihan, implementasi, program di lapangan dan sampai kepada evaluasi program latihan secara bertahap sesuai dengan tujuan yang ingin di capai. Menurut Syukur, A., \& Soniawan, V. (2015) sepakbola merupakan permainan yang membutuhkan banyak energi, kepintaran di dalam lapangan memacu semangat, sekaligus memberikankegembiraan melalui kebersamaan dalam sebuah tim. Dalam sepakbola terdapat bermacam teknik dasar bermain sepakbola.Teknik dasar merupakan fundamental yang harus dikuasai oleh semua atlet agar dapat bermain sepakbola dengan terampil yang didasari keterampilan multilateral gerak. Ada beberapateknikdalampermainanSepakbolayaitu: (1) teknik Tendangan (Kicking),(2)teknik menahan dan merebut Bola, (3) teknik mengontrol Bola(Ball Controll), (4) teknik sundulan (Heading). (5) teknik membawa bola(dribbling), (6)tekhnik menangkap bola(goal keeping), Salah satuteknik yang dominan digunakan atlet untuk menyerang dan bertujuan mencetak gol kegawang lawan adalahdengantekniksundulan(Heading). MenurutFekum Ariesbowo(2010:37)"Heading adalah teknik dasar yang penting dalam sepakbola, sundulan bukan hanya sekedar cara mengoper bola dengan kepala, melainkan juga dapat sebagai andalan untuk mencetak gol kegawang lawan".Oleh sebab itu semakin cepat dan tepat pergerakan tubuh maka bola semakin dapat disundul tajam kegawang dan memungkinkan untuk sulit diantisipasi oleh kiper lawan. Ada Konsep Dasar Yang Harus Dikuasai Dalam Melakukan Heading 1. Pada saat anda melihat kedatangan bola, bergeraklah ke arah bola itu untuk menghadang lajunya. 2. Perhatikan arah datangnya bola, dan terus perhatikan sampai bola tersebut menimpa kening anda. 3. Jangan memejamkan mata atau anda akan kesakitan, perhatikan arah gerakan bola yang datang dan menjauhi tubuh anda. 4 . Sundul bola itu dengan bagian atas kening anda, jangan memakai pelipis atau bagian atas kepala anda. 5. Gerakkan kepala anda ke belakang dan dengan kuat sundullah bola itu, jangan hanya diam dan membiarkan bola menimpa kepala anda. Robert Koger (2007:33) Menurut Danny Mielke (2007 : 49) Headingdapat memberikan dimensi yang sangat besar dalam permainan, para pemain bisa melakukan Heading ketika sedang meloncat, melompat kedepan, menjatuhkan diri (diving), atau tetap diam dan mengarahkan bola dengan tajam ke gawang atau teman satu team. MenurutRozi (2010:1) dalam jurnal Sumartani Tamping, menjelaskan keterampilan tekhnik dasar dalam menyundul bola (Heading)sebagai berikut: 1. Tahap Persiapan a) Berdiri kedua kaki di buka selebar bahu atau sikap melangkah, kedua lutut agak rendah. b) Kedua lengan di depan samping badan. c) Pandangan tertuju pada arah bola. 2. Tahap Gerakan a) Lentingkan pinggang ke belakang dan keraskan otot leher serta berat badan bertumpu pada kaki belakang. b) Arah pandangan pada bola. c) Gerakkan pinggang ke depan, hingga dahi tepat menyongsong arah datang nya bola. d) Untuk menambah kecepatan atau kekuatan bola, gerakkan kedua lengan ke belakang. 3. Akhir Gerakan a) Gerakan badan di bawa ke depan. b) Kedua lutut di luruskan serta kedua tumit terangkat dari tanah, Pandangan mengikuti arah gerak bola. Joseph A.Luxbacher (2012:103) juga menjelaskan bahwa Saat melakukan Heading berusahalah untuk mengontak bola pada titik tertinggi dari lompatan, tahan posisi badan yang melengkung hingga momen yang paling akhir, kemudian sentakkan badan ke depan ke arah bola, jaga agar leher dan kepala tidak bergerakAgar dapat melakukan 
Heading yang baik dalam permainansepakbola, seorang atlet harus mempunyai pergerakan yang cepat dan tepat dan memiliki daya ledak otot tungkai yang kuat. Menurut Bafirman (2008:82) "Daya Ledak adalah Salah satu dari komponen biomotorik yang penting dalam kegiatan olahraga, karena daya ledak akan menentukan seberapa keras orang dapat memukul seberapa jauh melempar, seberapa tinggi melompat, seberapa cepat berlari dan sebagainya" Menurut Arsil (2011:71) mengatakan"daya ledak (power) merupakan salah satu dari komponen biomotorik yang penting dalam kegiatan olahraga, karena daya ledak akan menentukan seberapa keras orang dapat memukul, seberapa jauh melempar, seberapa jauh melompat dan seberapa jauh berlari". Arsil (2011:73) juga mengatakan daya ledak di bagi atas dua jenis yaitu: 1)daya ledak Asiklik, 2) daya ledak Siklik Arsil(2011:74) mengungkapkan daya ledak di bagi atas dua macam:1) Power absolute bearti kekuatan untuk mengatasi suatu beban eksternal yang maksimum, 2) Power relatif bearti kekuatan yang digunakan untuk mengatasi beban berupa berat badan sendiri, Bafirman (2008:85) juga menjelaskanfaktor-faktor yang mempengaruhi power antara lain: 1 . Kekuatan otot a. Kekuatan maksimal b. Kekuatan daya ledak c. Kekuatan daya tahan 2. Kecepatan kontraksi otot. Power (kekuatan) yang di maksud adalah daya ledak otot tungkai yaitu merupakan kekuatan otot tungkai dalam mengatasi tahanan atau beban dalam suatu gerakan utuh dengan kecepatan yang singkat. Henri Irawadi(2001:98) menyatakan bahwa faktor yang mempengaruhi daya ledak otot ialah terbagi atas: a) Jenis serabut otot Pada tubuh manusia ada dua jenis serabut otot, yaitu serabut otot yang berwarna merah dan serabut otot berwarna putih. Serabut otot berwarna merah bereaksi lebih lambat(slow twitch fiber).jenis sering juga di sebut dengan otot kedut lambat. Sedangkan serabut otot berwarna putih, cendrung bereaksi lebih cepat(fast twitch fiber) otot ini sering di sebut otot kedut cepat. b) Panjang otot Panjang serat otot ternyata juga mempengaruhi kecepatan, Otot yang mempunyai serat lebih panjang daya kontraksi nya lebih cepat di banding otot yang mempunya serat pendek. c) Kekuatan otot Otot yang kuat ternyata mempengaruhi terhadap kecepatan gerak, Otot yang lebih kuat bergerak atau bereaksi lebih cepat daripada otot yang lemah. d) Bentuk otot Otot yang berjalan sejajar atau paralel terhadap sumbu longitudinal mempunyai daya kontraksi lebih tinggi dari pada otot yang berjalan diagonal terhadap sumbu longitudinal. e) Suhu otot Suhu otot mempengaruhi tingkat kesiapan otot. Otot yang berada pada suhu yang cukup panas akan beraksi (berkontraksi) lebih cepat dibanding otot dalam suhu yang dingin. f) Jenis Kelamin Perbedaan jenis kelamin ternyata juga mempengaruhi kecepatan, laki-laki cendrung lebih cepat dibandingkan perempuan. g) Kelelahan Kelelahan otot sangat mempengaruhi kontraksi otot, otot yang berada dalam keadaan lelah beraksi lebih lambat dibanding dengan otot dalam keadaan segar ( tidak lelah). h) Kordinasi Intermuskuler Kordinasi Intermuskuler atau interaksi beberapa otot sewaktu melakukan aktifitas. Pada setiap aktifitas jamani yang memerlukan kekuatan biasanya melibatkan beberapa kelompok otot. i) Kordinasi intramuskuler Dimana kekuatan (hasil daya) juga tergantung pada fungsi saraf otot yang terlibat dalam pelaksanaan tugas aktifitas fisik tersebut. Semakin banyak serabut otot dalam suatu aktifitas maka semakin besar kekuatan yang dihasilkan, begitu pula sebaliknya. j) Reaksi Otot terhadap rangsangan saraf Reaksi Otot terhadap rangsangan saraf otot akan memberikan reaksi terhadap rangsangan latihan sebesar 30 persen potensi yang dimiliki otot yang bersangkutan. k) Sudut sendi Beberapa penemnuan menyatakan bahwa kekuatan maksimum akan dicapai apabila sendi yang terlibat saat aktifitas berada pada keadaan benar benar lurus atau mendekati keadaan itu Menurut Hendri Irawadi (2011-96) "Daya ledak Otot merupakan gabungan beberapa unsur fisik yaitu unsur kekuatan dan unsur kecepatan,artinya kemampuan daya ledak otot dapat dilihat dari hasil sesuatu unjuk kerja yang dilakukan dengan mengunakan kekuatan dan kecepataan." Makin tinggi daya ledak otot seseorang maka semakin tinggiunsur kekuatan dan kecepatannya,oleh karena itu daya ledak otot tungkai dalam cabang olahraga sepakbola sangat penting dimiliki dan ditingkatkan oleh setiap atlet sepak bola. Klub Panti Putra Kabupaten Pasaman merupakan salah satu klub sepak bola di Kabupaten Pasaman yang terdiri dari satu Tim yang dibina oleh pelatih yang bernama Desrizal,klub ini telah mengikuti beberapa pertandingan antar klub sekabupaten Pasaman, bahkan telah sering mengikuti pertandingan di luar Sumbar sejak tahun 2000. Berdasarkan observasi yang dilakukan pada atlet klub Panti Putra Kabupaten Pasaman, diketahui bahwa dalam latihan maupun pertandingan masih banyak 
atlet yang memiliki tingkat daya ledak otot tungkai yang masih rendahyang mana terlihat saat sulitnya atlet MelakukanHeading pada saat atlet ingin mencetak gol ke gawang lawan yang terlihat saatsulitnya atlet melakukanHeadingdi depan gawang lawan. Menurut informasi dari pelatih klubPanti Putra Kabupaten Pasaman kemampuan tingkat daya ledak otot tungkai yang masih rendahdan lemah yang terlihat masih lambatnya pergerakan atlet saat melakukanHeading, kemampuan Headingyang masih rendah disebabkan karna sulitnya atlet melakukan lompatandengan cepat dan tepat. Dengan demikian dapat dikatakan bahwa kemampuan Headingatlet Panti Putra Kabupaten Pasaman masih rendah.Rendahnya kemampuan Heading disebabkan beberapa faktor, antara lain: (1)bentuk latihan seperti Jump To Box(Melompat kekotak), (2)skipping(Lompat tali), (3)sguat jump (jongkok - melompat), (4)squat thrust (jongkok-berdiri). Disamping bentuk latihan banyak lagi hal-hal yang mempengaruhi daya ledak otot tungkai seperti: (1) kurangnya sarana dan prasarana, (2)Gizi, (3)disiplin, (4)dan pelatih yang kurang profesional dalam membuat program latihan.Dari faktor-faktor penyebab rendahnya kemampun Headingatlet sepakbola klub Panti Putra Kabupaten Pasaman, penulis memilih salah satu bentuk latihan yaitulatihanJump To Box (Melompat Kekotak). Karena denganlatihanJump To Boxiniakanmemperolehkegunaan yang sangat banyak untuk meningkatkan daya Ledak Otot tungkai dalam melakukan Heading. Selainbermanfaat banyak, latihanJump To Box juga sangat sederhana dan bisa dilakukan dimana saja, Jump To Box merupakan salah satu bentuk latihan Pliometrik yang mana bertujuan untuk meningkatkan daya ledak otot. Jump To Boxmemiliki kelebihan yaitu, meningkatkan power otot kaki,meningkatkan kebugaran dan daya tahan, sedangkan kelemahanya antara lain, mudah melelahkan dan jika tidak dilakukan dengan cermat dapat menyebabkan cedera. Pada latihan Jump To Box, tinggi lompatan yang dilakukan berubah-ubah, sesuai dengan ukuran box yang di butuhkan.ketika kaki menumpuh pada box beban yang diterima oleh otot kaki saat mendarat akan lebih besar. Menurut Bafirman(2008:89) Pliometrik adalah sebuah metode latihan untuk pengembangan kemampuan eksplosif. Radclife (1985) memaparkan bahwa latihanlatihan pliometrik ini sangat bermanfaat untuk permainan sepak bola ketika melompat untuk melakukan Heading, tujuan dari latihan Pliometrikyaitu membantu para atlet untuk dapat mengembangkan daya ledak. yang sangat di butuhkan hampir di semua cabang olahraga. Salah satu bentuk latihan Pliometrik untuk meningkatkan daya ledak otot tungkai adalah latihan Jump To Box. Latihan Jump ToBox adalah latihan meloncat ke atas kotak balok kemudian meloncat turun kembali seperti sikap awal dengan menggunakan kedua tungkai bersama-sama. Donald A. Chu, (1992:48) Dalam jurnal mufidatul hasanah (2013:27) Jump ToBox merupakan latihan khusus untuk meningkatkan power otot tungkai. Otot-otot yang dikembangkan pada latihan Jump To Box antara lain flexi paha, ekstensi lutut, aduksi dan abduksi Uraian gerakan JumpTo Boxadalah sebagai berikut : Awalan : Berdiri dengan posisi kaki membuka selebar pinggul Pelaksanaan : 1. Posisi badan menghadap ke kotak. 2. Jongkok sedikit dan langsung melompat dari tanah ke kotak. 3. Gunakan lengan ayun ganda 4. Kaki mendarat ke tanah secara spontan 5. Dan ulangi 1. Keuntungan latihan pliometrik jump to box a. Otot bagian tungkai lebih cepat berkontraksi. b. Mudah dilakukan dan gerakan simpel. c. Dapat di lakukan dimana saja baik di dalam ruangan maupun di luar ruangan. 2. Kelemahan Jump To Boxa. Lebih cepat lelah karena pada waktu melompat ke box permukaanya lebihtinggi dari pada permukaan pada saat tolakan awalan. b. Gerakan semakin lama semakin melambat. c. Stamina lebih cepat terkuras.Donald A. Chu, (1992:28) di jurnal (mufidatul hasanah2013:27)

\section{METODE}

Penelitian ini bersifat eksperimen. Dilihat dari lokasi penelitian, maka penelitian ini termasuk jenis penelitian Eksperimen semu. Adapun variabel bebasnya adalah latihanjump To Box dan variabel terikatnya adalah kemampuan Headingatlet sepak bola klub Putra Panti Kabupaten Pasaman. Penelitian ini terdiri dari satu kelompok sampel yang akan melakukan bentuk latihan (perlakuan) yang sama. Sebelum dilakukan latihan, terlebih dahulu dilakukan tes awal (pretest), selanjutnya selama 16 kali pertemuan kelompok diberikan perlakuan (latihan), setelah itu dilakukan tes akhir (posttest). Oleh karena itu, rancangan penelitian ini adalah :pre-test danpost test one group design. Populas penelitian ini adalah keseluruhan objek 
yang ingin diteliti. Hal ini sesuai dengan pendapat yang dikatakan oleh Putrawan (1990:5-7) yaitu" Populasi merupakan seluruh data yang menjadi perhatian kita dalam suatu ruang lingkup dan waktu yang kita tentukan.".Populasi dalam penelitian ini adalah atlet Sepakbola klub Panti Putra sebanyak 43 orang Penelitian ini di mulai pada tanggal 19 februari 2015 yang dilaksanakan di lapangan maninjau Kabupaten Pasaman. Sampel penelitian ini diambil dari Populasiatlet junior sebanyak 20 orang.Dalam penelitian ini pengambilan sampel dilakukan dengan teknik "Proposivesampel".Proposive sampel ialah teknik Pengambilan sampel secara sengaja sesuai dengan persyaratan sampel yang diperlukan, peneliti menentukan sendiri sampel yang diambil karena pertimbangan tertentu, jadi sampel diambil tidak secara acak, tapi di tentukan sendiri oleh peneliti. Tabel 2. Populasi Atlet Klub Panti

Putra Pasaman

\begin{tabular}{|c|c|}
\hline Senior & 23 \\
\hline Junior & 20 \\
\hline
\end{tabular}

Berdasarkan teknik pengambilan sampel, peneliti mengambil sampel dalam penelitian ini 20 orang atlet junioryang merupakan atlet sepakbola yang tergabung dalam Klub sepakbola Panti Putra, Tes yang dilakukan adalah HeadingTest. Penelitian ini dapat diolah dengan memakai statistik deskriptif dan inferensial,untuk menganalis hasil eksperimen yang menggunakanpre-test dan post-test one group designdesain dengan rumus Arikunto (2010:309).

\section{HASIL DAN PEMBAHASAN}

Uji normalitas dilakukan dengan uji Lilliefors dengan taraf signifikan 0,05 dengan hasil dari pengujian persyaratan sebagai berikut: Uji normalitas dilakukan dengan uji Lilliefors, hasil uji normalitas terhadap variabel penelitian yaitu hasil kemampuan Heading (pretes dan postes).

Tabel 6. Uji Normalitas Data Pretes dan Post tes

\begin{tabular}{|c|c|c|}
\hline Variabel & Lhitung & Ltabel \\
\hline Data Pretest & 0,827 & 0,190 \\
\hline Data Postest & 0,516 & 0,190 \\
\hline
\end{tabular}

Dari Tabel diatas terlihat bahwa data pretes setelah dilakukan perhitungan menghasilkan Lhitung sebesar 0,827 dan Ltabel sebesar 0,190.Ini berarti Lhitung lebih besar dari Ltabel.Dapat disimpulkan penyebaran data pretes berdistribusi normal.Untuk pengujian data hasil postes menghasilkan Lhitung sebesar 0,516 dan Ltabel sebesar 0,190.Ini berarti Lhitung lebih besar dari Ltabel.

Hipotesis yang diuji dalam penelitian ini adalah: Ho: Tidak terdapat pengaruh yang signifikan antara latihan Jump to Box (X) terhadap hasil Kemampuan Heading (Y) pada Atlet Klub Panti Putra Kabupaten Pasaman. H1: Terdapat pengaruh yang signifikan antara latihan Jump to box (X) terhadap hasil Kemampuan Heading(Y) pada Atlet Klub Panti Putra Kabupaten Pasaman. Data yang diperoleh dianalisis secara deskriptif, maka selanjutnya dilakukan pengujian hipotesis penelitian yang telah diajukan sesuai masalah yaitu: "terdapat pengaruh latihan Jump to Boxyang signifikan dengan hasil Kemampuan heading (Y). Berdasarkan analisis uji T menghasilkan thitungsebesar 6,734 dan t tabel sebesar 2,093.Berarti thitung > ttabel. Dapat disimpulkan bahwa H0 ditolak dan H1 diterima. Dapat disimpulkan bahwa terdapat pengaruh yang signifikan antara latihan Jump to Box (X) dengan hasil Kemampuan Heading (Y) pada Atlet Klub Panti Putra Kabupaten Pasaman pada taraf alfa 0,05 dengan tingkat kepercayaan $95 \%$. 


\section{KESIMPULAN}

Berdasarkan hasil temuan dan pengolahan data yang dilakukan dapat disimpulkan berdasarkan tabel distribusi t dengan derajat kebebasan (dk) $n-1=20-1=19$ taraf signifikan 0,05 , maka diperoleh ttabel $=2,093$. Jadi thitung $>$ ttabel $=6,734>2,093$ maka Ho di tolak sedangkan Ha diterima. Kesimpulan, terdapat pengaruh yang signifikan dari latihan Jump to boxterhadap kemampuan heading.

\section{DAFTAR RUJUKAN}

Ariesbowo Fekum. (2010). Menjadi pemain sepakbola yang tangguh.Jakarta : Be Champion.

Arsil. (2011). Pembinaan Kondisi Fisik. Padang: Sukabina.

Arwandi, J., \& Ardianda, E. (2018).Latihan Zig-Zag Run Dan Latihan Shuttle Run Berpengaruh Terhadap Kemampuan Dribbling Sepakbola.Performa, 3(01), 32-32.

Bafirman(2008) pembentukan kondisi fisik.Padang: UNP.

Donald A. Chu, (1992:48) "pengaruh latihan pliometrik depth jump dan jump to box terhadap power otot tungkai pada atlet bolavoli klub tugum uda kota semarang”pada jurnal Mufidatul Hasanah (2013).

Haryanto, J., \& Welis, W. (2019). Exercising Interest in the Middle Age Group. Performa Olahraga, 4(2), 214-223. https://doi.org/https://doi.org/10.24036/k epel.v4i02.131.

Irawadi.Hendri.(2011). Kondisi Fisik Dan Pengukurannya.FIK. UNP: Padang.

Koger Robert. (2007). Latihan Dasar Andal Sepak Bola Remaja, Latihan dan Ketermpilan Andal Untuk Pertandingan Dasar Yang Lebih Baik.Klaten: Saka Mitra Kompetensi.

Luxbacher A Joseph. (2012) Sepak Bola. Jakarta: Rajawali Pers.

Menpora.(2007). Undang-Undang RI Nomor 3 Tahun 2005.Tentang Sistem Koelahragaan Nasional Bandung: Citra Umbara.

Mielke Danny. (2007). Dasar Dasar Sepakbola. Bandung: Human Kinetics.

Nawawi Umar. (2007). Fisiologi Olahraga.FIK. UNP Padang

Ridwan, M., \& Irawan, R. (2018). Validitas Dan Reliabilitas Tes Kondisi Fisik Atlet Sekolah Sepakbola (Ssb) Kota Padang "Battery Test Of Physical Conditioning". Performa Olahraga, 3(02), 90-90.

Rozi.(2010) "Meningkatkan Ketrampilan Heading Permainan Sepak BolaMelalui Latihan Lompat Lompat di Tempat Siswa Kelas V SDN Inpres Cemerlang” pada jurnal Sumartani Tamping.

Soniawan, V., \& Irawan, R. (2018).Metode Bermain Berpengaruh Terhadap Kemampuan Long Passing Sepakbola.Performa Olahraga, 3(01), 42-42.

Syafruddin.(2011). ilmu kepelatihan olahraga.teori dan aplikasi dalam pembinaan olahraga.Padang: UNP PREES. 
Syukur, A., \& Soniawan, V. (2015).THE EFFECTS OF TRAINING METHODS AND ACHIEVEMENT MOTIVATION TOWARD OF FOOTBALL PASSING SKILLS.JIPES-JOURNAL OF INDONESIAN PHYSICAL EDUCATION AND SPORT, 1(2), 73-84.

Zalfendi.(2010) Buku Ajar Sepak Bola.Padang: Sukabina. 